\title{
EFFECT OF DURATION BREASTFEEDING TOWARD def-t INDEX OF 2-3 YEARS OLD CHILD IN POSYANDU PUSKESMAS
}

\author{
Ummu Hanifah Amri ${ }^{1}$, Harfindo Nismal ${ }^{2}$ \\ Faculty of Dentistry Andalas University
}

\begin{abstract}
There are main factors that play role in the occurrence of caries, those are host factors, microorganism, substrate, and time. If one factor is not there then caries does not occur. Breastfeeding is fat emulsion in a solution of protein, lactose, and organic salt that are secreted by the breast. Breastfeeding contains nutrients that can inhibit caries occurrence. The aim of this study is to determine effect of duration breastfeeding toward def-t Index of 2-3 years old child in Posyandu Puskesmas Andalas. This study design is an observational with cross sectional design. The total sample were 68 of 2-3 years old children in Posyandu Puskesmas Andalas. The analysis effect of duration breastfeeding toward def-t Index is Chi Square's Test. This study shows that there are significant effect $(p<0,05)$ between duration breastfeeding toward def-t Index of 2-3 Years Old Child. def- $t$ Index the moderate category for $\geq 6$ months breastfeeding and def-t index the high category for $<6$ months breastfeeding.There is effect duration breastfeeding toward def-t Index of 2-3 years old.
\end{abstract}

Key words : Breastfeeding, def-t Index, caries

Affiliasi penulis : Faculty of Dentistry Andalas University

Korespondensi: Ummu Hanifah Amri

Email : ummuhanifahamri1994@yahoo.co.id

\section{PENDAHULUAN}

Karies gigi adalah penyakit infeksi dan merupakan suatu proses demineralisasi yang progresif pada jaringan keras permukaan gigi oleh asam organik yang berasal dari makanan yang mengandung gula. Karies merupakan penyakit yang paling banyak dijumpai di rongga mulut bersama-sama dengan penyakit periodontal, sehingga merupakan masalah utama kesehatan gigi dan mulut. Pendapat lain mengatakan karies merupakan penyakit jaringan gigi yang ditandai dengan kerusakan jaringan, dimulai dari permukaan gigi (email gigi, fisura, dan daerah interproksimal) meluas ke arah pulpa. ${ }^{1,2}$

\section{Patofisiologi Karies}

Menurut Miller (1884) di dalam cairan air ludah dijumpai banyak sekali enzim seperti amilase, maltosa, selain enzim-enzim yang dikeluarkan mikroorganisme dan jamur-jamur yang terdapat dalam mulut. Enzim-enzim tersebut misalnya amilase, dapat mengubah polisakarida menjadi glukosa dan maltosa. Oleh karena penguraian dari enzim-enzim yang dikeluarkan mikroorganisme tersebut akan menghasilkan asam susu atau laktat 
yang akan merusak bahan-bahan anorganik dari email sehingga terbentuk lubang kecil. ${ }^{2}$

\section{Teori Glikogen}

Egyede

mengemukakan

hipotesisnya bahwa glikogen dalam

keadaan normal dijumpai bersama-sama dengan bahan-bahan organik dari email seperti keratin. Bila konsumsi karbohidrat meningkat terutama pada wanita hamil dan bayi, glikogen pada jaringan gigi juga bertambah. Glikogen merupakan bahan makanan mikroorganisme mulut sehingga oleh enzim glikogenase akan diuraikan menjadi glukosa. Oleh proses demineralisasi, glukosa ini akan dipecah lagi menjadi asam susu sehingga proses terbentuknya karies akan berlanjut. ${ }^{2}$

\section{Teori Multifaktor}

Merupakan konsep baru mengenai teori terjadinya karies gigi, dikatakan bahwa karies gigi adalah suatu penyakit multifaktor, ada empat faktor yang memegang peranan yaitu tuan rumah yang terdiri dari host (gigi dan saliva), agent yang berupa mikroorganisme yang kariogenik, dan substrat yang terdiri dari makanan seperti monosakarida dan disakarida, dan ditambah dengan faktor waktu. Untuk terjadinya karies gigi maka kondisi dari setiap faktor harus saling mendukung. Bila salah satu faktor tidak ada maka tidak akan terjadi karies. ${ }^{2}$

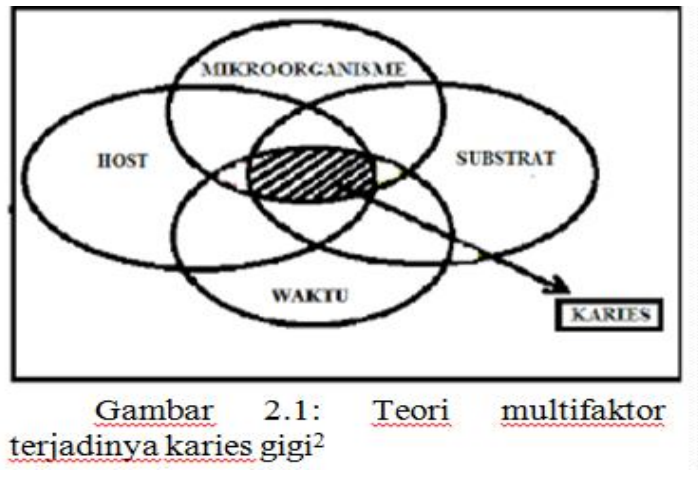

Indeks Karies

Indeks adalah ukuran yang dinyatakan dengan angka dari keadaan suatu golongan/ kelompok terhadap suatu penyakit gigi tertentu. Ukuran-ukuran ini dapat digunakan untuk mengukur derajat keparahan dari suatu penyakit mulai dari yang ringan sampai berat. Untuk mendapatkan data tentang status karies seseorang digunakan indeks karies agar penilaian yang diberikan pemeriksa sama atau seragam. Ada beberapa indeks karies yang digunakan seperti indeks Klein dan indeks WHO, namun belakangan ini diperkenalkan Significant indeks Caries (SiC) untuk melengkapi indeks WHO sebelumnya. ${ }^{3}$

Indeks karies gigi yang bisa digunakan adalah untuk gigi desidui adalah indeks deft. Indeks def-t (decayed, extracted, filled teeth) diperoleh dengan menghitung keadaan sebagai berikut :

d: Apabila jaringan email gigi desidui mengalami dekalsifikasi, terlihat keputihputihan atau kecoklatan dengan ujung ekskavator/ sonde yang terasa menyangkut pada kavitas. Keadaan lain yang termasuk 
ke dalam kategori ini, yaitu: karies dengan kavitas besar yang melibatkan dentin, karies mencapai jaringan pulpa baik pulpa tersebut masih vital maupun non-vital, walaupun pada gigi tersebut terdapat restorasi. Seluruh keadaan ini masih dikategorikan d (decayed), apabila kavitas tersebut nantinya masih dapat direstorasi.

e: Apabila gigi desidui tersebut telah dilakukan pencabutan atau tanggal. Keadaan lain yang termasuk ke dalam kategori ini yaitu karies gigi desidui yang diindikasikan untuk pencabutan, contohnya jika mahkota gigi tidak ada atau yang ada hanya sisa akar.

f: Apabila pada gigi desidui tersebut telah ditumpat atau direstorasi secara tetap maupun sementara. Apabila gigi yang sudah ditumpat terdapat karies maka tidak akan termasuk kedalam kategori ini.

Angka def-t menggambarkan banyaknya karies yang diderita seseorang. Pengertian def-t karies dihitung per gigi, artinya gigi yang memiliki karies lebih dari 1 (misalnya karies pada gigi molar 1 terdapat karies di oklusal dan di bukal maka karies tetap dihitung satu).

Indeks def- $\mathrm{t}=\mathrm{d}+\mathrm{e}+\mathrm{f}$ Indeks def- $\mathrm{t}$ rata-rata $=$

Jumlah indeks def-t semua responden

Jumlah responden

Kriteria penilaian indeks def-t rata- rata menurut WHO adalah:
1.Sangat Rendah : 0,0-1,12. Rendah $: 1,2-2,6$

3. Sedang : $2,7-4,4$

4. Tinggi : 4,5-6,5

5. Sangat Tinggi : > 6,6

Skala skor def-t Individu menurut Gruebbel AO (1994) deft $0-2=$ Rendah

1. Skor deft 3-5= Sedang

2. Skor deft $\geq 6=$ Tinggi

Penelitian di AS menyatakan bahwa berbagai penelitian epidemiologi menunjukkan bahwa ASI sangat bermanfaat bagi kesehatan anak. Anak yang diberi ASI mempunyai riwayat infeksi saluran pencernaan dan saluran pernafasan yang lebih rendah daripada anak yang tidak diberi ASI. Tingginya daya tahan ini berhubungan dengan perlindungan pasif yang diberikan oleh substansi antimikroba yang terdapat pada ASI diantaranya laktoferin, lisozim dan secretory imunoglobulin A atau sIgA. ${ }^{5}$

ASI mengandung berbagai zat yang berfungsi sebagai sistem pertahanan nonspesifik dan spesifik. Pertahanan nonspesifik diperankan oleh beberapa sel, seperti makrofag, neutrofil serta faktor protektif larut (laktoferin dan lysozim). Pertahanan spesifik diperankan oleh sel $\operatorname{limfosit}(\operatorname{sIg} \mathrm{A}){ }^{6}$

Peran antimikroba dari laktoferin dan lisozim ini diduga merupakan faktor terpenting dari imunitas nonspesifik. SIgA 
pada ASI berperan sebagai imunitas protein pasif terhadap antigen dan mikroorganisme. Laktoferin adalah protein yang bersifat bakteriostatik. Fungsi bakteriostatik laktoferin dengan cara mengikat ion $\mathrm{Fe} 3+$ agar tidak digunakan oleh bakteri untuk bertumbuh kembang. Laktoferin mampu menghambat perkembangan jamur dan bakteri yang merugikan kesehatan bayi. ${ }^{7,8}$

Lisozim merupakan enzim yang melindungi bayi terhadap bakteri dan virus. Lisozim memiliki aktivitas muramidase yaitu mampu menghidrolisa ikatan Beta antara asam $\mathrm{N}$-asetil muramik dan $\mathrm{N}$ asetilglukosamin pada lapisan peptidoglikan dinding sel bakteri. Hidrolisa lapisan peptidoglikan akan melisis bakteri. Lisozim mampu memecah dinding bakteri yang merugikan (bakteriosidal) sehingga menjadi porous dan bakteri kehilangan cairan sel yang secara tidak langsung dapat meningkatkan keefektifan antibodi. ${ }^{7,8}$

ASI mengandung sekretori IgA dan memiliki kapasitas buffer yang dapat menghambat proses terjadinya karies. Antibodi IgA mengganggu kolonisasi awal Streptococcus mutans. Kandungan nutrisi, kapasitas buffer dan mekanisme pertahanan lain dalam ASI menghambat pertumbuhan mikroorganisme dalam rongga mulut. ASI memiliki kapasitas buffer dan kemampuan meningkatkan remineralisasi email dengan mendeposit $\mathrm{Ca}$ dan $\mathrm{P}$ pada permukaan email, ASI memiliki mekanisme pertahanan kompleks yang menghambat pertumbuhan mikroorganisme, termasuk Streptococcus mutans. $^{9}$

Imunoglobulin A ditemukan dalam jumlah sedikit dalam serum, tetapi kadarnya dalam sekresi saluran nafas, saluran cerna, saluran kemih, air mata, keringat, ludah dan ASI lebih tinggi dalam bentuk IgA sekretori ( $\operatorname{sIg}$ A ). SIgA dalam ASI ditransfer ke bayi yang merupakan imunitas yang didapatkan anak dari ibu. Baik IgA dalam serum maupun dalam sekresi dapat menetralisir toksin atau virus dan mencegah terjadinya kontak antara toksin atau virus dengan sel organ sasaran. IgA dalam serum dapat mengganggu motilitas kuman sehingga memudahkan fagositosis. SIgA dapat mencegah kontak antara mikroorganisme dengan selaput lendir sehingga mikroorganisme tidak akan dapat menembus dan berkembang biak dalam tubuh. SIgA juga dapat menetralisir toksin dan meningkatkan efek bakteriolitik .

\section{METODE PENELITIAN}

Jenis penelitian yang digunakan adalah rancangan penelitian analytic observation dengan studi cross sectional. Rancangan cross sectional merupakan rancangan penelitian dimana variabel independen dan variabel dependen diobservasi sekaligus pada waktu yang sama. Metode cross 
sectional pada penelitian ini yaitu mengumpulkan data pada satu waktu untuk menganalisis pengaruh durasi pemberian ASI terhadap indeks def-t pada anak usia 2-

3 tahun di Posyandu wilayah kerja Puskesmas Andalas. Penelitian ini dilakukan di Posyandu wilayah kerja Puskesmas Andalas. Waktu penelitian ini dimulai pada bulan Maret 2016 sampai selesai. Sampel dipilih sesuai kriteria inklusi yang berjumlah

68 orang. Sampel diberikan informasi sebelum dilakukan kegiatan penelitian. Kegiatan penelitian terdiri atas pengisian kuesioner, penandatanganan informed consent, serta pemeriksaan klinis rongga mulut

\section{HASIL PENELITIAN}

Analisis univariat dilakukan untuk mengetahui distribusi frekuensi dari variabel-variabel yang diteliti. Pada analisis univariat akan menggambarkan karakteristik sampel penelitian.

Karakteristik sampel dalam penelitian ini meliputi jenis kelamin, durasi pemberian ASI dan indeks def-t dari sampel penelitian di Posyandu wilayah kerja puskesmas Andalas.

\section{Distribusi Sampel Berdasarkan Jenis Kelamin}

Dalam penelitian ini yang menjadi subjek penelitian adalah anak-anak yang berumur 2-3 tahun yang berjumlah 68 orang yang berada di Posyandu wilayah kerja Puskesmas Andalas. Untuk distribusi jenis kelamin, sampel perempuan lebih banyak dibandingkan sampel laki-laki.

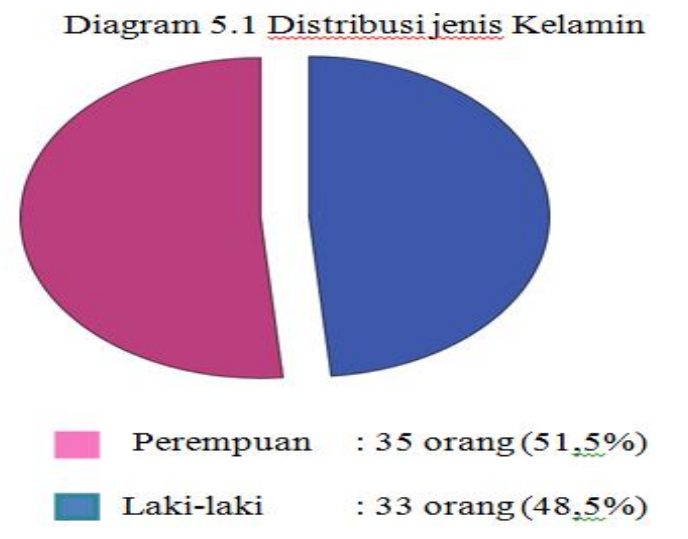

Berdasarkan Diagram 5.1 diatas dapat dilihat bahwa jumlah anak perempuan lebih banyak yaitu 35 anak (51,5\%) dibandingkan jumlah anak laki - laki sebanyak 33 anak $(48,5 \%)$.

\section{Durasi Pemberian ASI}

Berdasarkan wawancara kepada sampel (ibu) di Posyandu wilayah kerja Puskesmas Andalas didapatkan data bahwa sebagian anak telah mendapatkan pemberian ASI $\geq 6$ bulan.

\begin{tabular}{|c|c|c|c|}
\hline \multicolumn{4}{|c|}{ Tabel 5.1 Durasi Pemberian ASI } \\
\hline Durasi Pemberian ASI & $\begin{array}{c}\text { Jumlah } \\
\text { Sampl }\end{array}$ & $\begin{array}{c}\text { Rata-rata土 sd } \\
\text { (Bulan) }\end{array}$ & $\begin{array}{c}\text { min-maks } \\
\text { (Bulan) }\end{array}$ \\
\hline 26 Bulan & 37 & $16.68 \pm 5.175$ & 6.24 \\
\hline$<6$ Bulan & 31 & $2.87 \pm 1.360$ & 0.4 \\
\hline Total & 68 & $10,38 \pm 7,950$ & 0.24 \\
\hline
\end{tabular}

Berdasarkan Tabel 5.1 diatas dapat dilihat rata-rata durasi pemberian ASI di Posyandu wilayah kerja Puskesmas Andalas adalah 10,38 bulan. Rata-rata 
pemberian ASI $\geq 6$ bulan adalah 16.68 bulan dan rata- rata pemberian ASI $<6$ bulan adalah 2.87 bulan.

Skor deft pada Pemberian ASI $\geq 6$ bulan dan $<6$ bulan

Berdasarkan hasil pemeriksaan didapatkan skor deft per individu. Skor deft didapatkan dari hasil penjumlahan decayed, extracted dan filling tooth.

\begin{tabular}{|c|c|c|c|c|}
\hline \multirow{2}{*}{$\begin{array}{c}\text { Pemberian } \\
\text { ASI }\end{array}$} & \multicolumn{3}{|c|}{ Kategori Skor deft } & \multirow[b]{2}{*}{ Total Sampel } \\
\hline & Rendah & Sedang & Timgg! & \\
\hline$\geq 6$ bulan & $\begin{array}{l}21 \text { orang } \\
(567 \%)\end{array}$ & $\begin{array}{l}13 \text { orang } \\
(355,1 \%)\end{array}$ & $\begin{array}{l}3 \text { orang } \\
(8.1 \%)\end{array}$ & $\begin{array}{l}37 \text { orang } \\
(100 \%)\end{array}$ \\
\hline$<6$ bulan & $\begin{array}{l}\text { 8orang } \\
(25.8 \%)\end{array}$ & $\begin{array}{l}12 \text { orang } \\
(38,7 \%)\end{array}$ & $\begin{array}{c}11 \text { orang } \\
(35,4)\end{array}$ & $\begin{array}{l}31 \text { orang } \\
(100 \%)\end{array}$ \\
\hline
\end{tabular}

Indeks deft pada Pemberian ASI $\geq 6$ bulan dan $<6$ bulan

Indeks deft didapatkan dari penjumlahan skor deft seluruh sampel dibagi dengan jumlah sampel. Dari hasil penelitian didapatkan bahwa Indeks deft pada sampel dengan pemberian ASI $<6$ bulan lebih tinggi dibandingkan sampel yang mendapatkan ASI $\geq 6$ bulan.

\begin{tabular}{|c|c|c|c|}
\hline \multicolumn{4}{|c|}{ 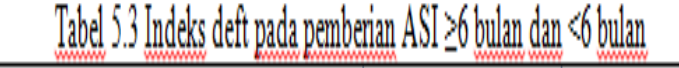 } \\
\hline Pemberian IS & Jumblh Sampe & Jumbh Skordeft & Indess de \\
\hline solutan & 37 & 100 & 2,70 \\
\hline sobulan & 31 & 143 & 4,01 \\
\hline
\end{tabular}

Analisis bivariat ini bertujuan untuk membuktikan ada tidaknya pengaruh yang bermakna antara variabel independen (Durasi pemberian ASI $\geq 6$ bulan dan $<6$ bulan) dengan variabel dependen (Indeks def-t) dengan menggunakan uji statistik chi square. Uji ini dilakukan karena variabel dependen dan independen merupakan variabel katagorik.

Tabel 5.4 Pengaruh durasi pemberian $₹ 6$ bulan dan $<6$ bulan terhadap Indeks deft

\begin{tabular}{|c|c|c|c|}
\hline Pemberian ASI & Indeks deft & Kategori & Nilai P \\
\hline >6 bulan & 2,70 & Sedang & \multirow{2}{*}{0,000} \\
\hline <6 bulan & 4,61 & Tinggi & \\
\hline
\end{tabular}

Dari tabel diatas didapatkan nilai $\mathrm{P}$ sebesar 0,00 dimana nilai tersebut $<0,05$. Hasil hipotesa diterima sehingga dapat dinyatakan bahwa terdapat pengaruh durasi pemberian ASI terhadap indeks def-t anak usia 2-3 tahun di Posyandu wilayah kerja Puskesmas Andalas.

\section{KESIMPULAN}

Berdasarkan penelitian yang telah dilakukan pada anak usia 2-3 tahun di Posyandu wilayah kerja Puskesmas Andalas, maka dapat disimpulkan sebagai berikut:

1. Terdapat pengaruh yang bermakna antara durasi pemberian ASI terhadap indeks def-t anak usia 2-3 tahun.

2. Sebanyak $54,4 \%$ sampel mengkonsumsi ASI $\geq 6$ bulan.

3. Indeks def-t anak yang mengkonsumsi ASI $\geq 6$ bulan adalah 2,70 termasuk kategori sedang. 
4. Indeks def-t anak yang

mengkonsumsi ASI $<6$ bulan

adalah 4,61 termasuk kategori

tinggi.

\section{KEPUSTAKAAN}

1. Newburn E. Cariology: Quintessence publishing company.1989.

2. Tarigan R. Karies gigi. 2nd .ed. Jakarta: EGC, 2012.

3. Pintauli S, Hamada T. Menuju gigi dan mulut sehat. USU Press. 2008.

4. Verma S, Bansal K, Singhal S. Correlation between early childhood caries and maternal caries status and influence of preventive educational conseling on children's S. mutans levels. 2015

5. Hennart PF, Brasseur DJ, DelogneDesnoeck JB, Dramaix MM, Robyn CE. Lysozyme, lactoferrin, and secretory immunoglobulin A content in breast milk: influence of duration of lactation, nutrition status, prolactin status, and parity of mother. 1991

6. Prasetyono DS. Buku pintar ASI eksklusif. 2nd rev.ed. Yogyakarta: Diva Press, 2009.

7. Maryunani A. Inisiasi menyusui dini, ASI eksklusif dan manajemen laktasi. 1st.ed. Jakarta: Trans Info Media, 2012. $11 \mathrm{p}$.

8. Arisman. Gizi dalam daur kehidupan. 1st.ed. Jakarta: EGC, 2004.

9. Marcotte H, Lavoice MC. Oral microbial ecology and the role of salivary immunoglobulin A. 1998 